\title{
Kimberley marine biota. Historical data: additional phyla (Brachiopoda, Bryozoa, Annelida, Platyhelminthes, Sipuncula, Cnidaria and Chordata)
}

\author{
Clay Bryce ${ }^{1^{*}}$ and Alison Sampey ${ }^{1}$ \\ 1 Department of Aquatic Zoology, Western Australian Museum, Locked Bag 49, Welshpool DC, \\ Western Australia 6986, Australia. \\ * Email: clay.bryce@museum.wa.gov.au
}

\begin{abstract}
This is the final paper in this series on historical marine biodiversity records of the Kimberley, north-western Australia from the Woodside Collection Project (Kimberley) 2009-2015. Here we document the historical records of seven additional phyla extracted from collection data from three Australian museums participating in the project. Although these data were not included as targeted project taxa and are too few for meaningful statistical analyses or comparison, they are of interest for their historical value (oldest specimens and presence data), the baseline information the data contain, and for highlighting the significant knowledge gap they represent. Within the seven phyla, 121 species are recorded from 44 locations in the Project Area, with $48.6 \%$ of the original records excluded for reasons explained in Sampey et al. (2014).
\end{abstract}

KEYWORDS: natural history collections, species inventory, biodiversity, NW Australia, baseline data

\section{INTRODUCTION}

The utilisation of natural science collections to provide baseline biodiversity information to inform conservation and environmental management decisions is increasingly being recognised (Pyke and Ehrlich 2010; Costello et al. 2013). The Western Australian Museum (WAM) and other Australian natural science institutions have accumulated marine voucher records from the Kimberley Project Area (Project Area) (see Sampey et al. 2014 and defined below) since the late 1800s. This has resulted in significant collections of marine specimens with associated metadata. However, much of the data, and their interpretation, are either unpublished or published in specialist taxonomic literature, and thus not readily accessible to researchers and conservation managers. To address this situation WAM instigated the Woodside Collection Project (Kimberley) 2009-2015 (the Project) in conjunction with other Australian museums and the Western Australian Herbarium (WAH). The Project had two main components: an historical assessment of the known marine voucherbased records housed in Australian museum collections (Jones et al. 2017), and a series of marine biodiversity surveys undertaken during 2009-2014, with results currently in preparation.
The historical component (1880s-2009) collated records of shallow water $(<30 \mathrm{~m})$ marine flora and fauna (restricted to fishes and targeted invertebrate taxa) from the Project Area. The intent was to provide information on general trends in diversity patterns and collection gaps, both spatial and taxonomic, for these taxa.

The additional phyla included here were not targeted taxa for the Project, but were part of the original datasets, although their records were much fewer in number. Here we provide an inventory of the known records for these taxa. Because these phyla are represented by a small dataset comparative statistical analyses have not been undertaken.

\section{METHODS}

Full details of the Project methodology are outlined in Sampey et al. (2014).

The Project Area was defined by the coordinates $19.00^{\circ} \mathrm{S} 121.57^{\circ} \mathrm{E} ; 19.00^{\circ} \mathrm{S} 118.25^{\circ} \mathrm{E} ; 12.00^{\circ} \mathrm{S} 129.00^{\circ} \mathrm{E}$; $12.00^{\circ} \mathrm{S} 121.00^{\circ} \mathrm{E}$. It encompassed the coast, which formed a natural inshore boundary, from south of Broome to the Western Australian/Northern Territory border, extending beyond the $1000 \mathrm{~m}$ bathymetric contour to include the shelf edge atolls (Figures 1-5). 
Data for the phyla were sourced from the collection databases of the WAM, Australian Museum (AM) and Museum and Art Gallery of the Northern Territory (MAGNT) as per Sampey et al. (2014). Three of the phyla are only partially represented, with the Scleractinia (Richards et al. 2014) and Octocorallia (Bryce et al. 2014) removed from the Cnidaria, the class Polychaeta (Hutchings et al. 2014) removed from the Annelida, and the Ascidiacea being the only class included in the Chordata.

Species names were checked (30 July 2016 to 18 January 2017) using the World Register of Marine Species (WoRMS, 2014). The species taxonomic determinations were assigned to a geographical location in Table 1 and the following assessments provided: number of species per phyla, number of inshore and offshore species for each phyla, number of species co-occurring at both inshore and offshore sites, and number of geographical locations per phyla. Also provided are total species counts, and totals for species inshore, offshore, and at both inshore and offshore sites. Table 2 details location coordinates, data on collection years, species counts per location, number of collection events and total collecting events, and occurrences of phyla across each location.

Location distribution maps (Figures 1-5) were prepared for each phylum from data provided in Appendices 1 and 2. Figure 1 is a composite map displaying locations for Brachiopoda (4 locations), Annelida (2) and Platyhelminthes (1). Figure 2 displays the locations for the Sipuncula (11 locations); Figure 3 the Cnidaria (28); Figure 4 the Chordata (17) and Figure 5 the Bryozoa with 9 locations. All maps have the Project Area boundary marked in grey with a map projection GDA94 and a scale of 1:6, 250,000.

\section{RESULTS}

A total of 121 species from seven phyla are documented (Appendix 1), with $48.6 \%$ of the original data excluded for a number of reasons including that the data was beyond the scope of the project (i.e. wrong depth and/or geographical location), specimens were incompletely identified, and potential for taxonomic duplication as a result of taxonomic qualifiers (e.g. "aff.", "cf." and "?"). A full explanation of the data exclusion rationale used in the Project is provided in Sampey et al. (2014).

The number of species for each phylum was: Brachiopoda (3 species), Bryozoa (12), Annelida (3), Platyhelminthes (2), Sipuncula (5), Cnidaria (27) and Chordata (69). These species were from 44 locations (5 offshore and 39 inshore), with 47 species inshore, 86 offshore, and 12 species occurred both inshore and offshore. Inshore is here defined as extending from the coast to the $50 \mathrm{~m}$ bathymetric contour, with the offshore continuing seaward to the continental edge.

There were 56 separate collecting events associated with the 121 species, with 37 single and seven multiple events, of which six occurred in Broome, three at Ashmore Reef and five other locations hosted two collecting events each. Although Broome had most collecting events, only 13 species across six phyla within a 77 year collection period were recorded, while Ashmore Reef had 77 species from five phyla over 16 years, and with half the collecting events (Appendix 2).

The time period for the collecting events was from 1913 to 2002. The three oldest records were the sea jelly, Pseudorhiza haeckeli Haarke, 1884, collected in 1913 from Freshwater Bay; the brachiopod, Lingula adamsi Dall, 1873 collected from Broome in 1921 and the ascidian, Pyura arenosa (Herdman, 1882) from Kuri Bay in 1964 (Appendix 2).

\section{DISCUSSION}

Historical marine floral and faunal collections provide baseline biodiversity and ecological data, and are important references for contributing to the determination of biotic assessments and human impacts associated with marine environments. The papers of this series (Jones et al. 2017) have detailed the historical collections found in the Kimberley Project Area, and provide fundamental knowledge for future research.

The majority of species reported here from the Project Area were collected from offshore reefs: Ashmore Reef (77 species), Rowley Shoals (11) and Scott Reef (1). Due to their remote location and the dates of the collecting events these species counts can be attributed to museum survey work. Inshore, Broome (13 species) had six separate collecting events over a wide date range (1921-2002), suggesting ad hoc collecting rather than targeted effort.

The collation of data on these phyla clearly indicates a lack of expert collecting and taxonomic attention. This highlights the critical information gap associated with these phyla.

Wilson (2014) noted that the Kimberley marine 'minor phyla', including the Platyhelminthes, nemertines, brachiopods and bryozoans are virtually unstudied. In this data synthesis we note the relatively high number of ascidian species (69), and modest number of non-scleractinian and octocoral cnidarian species (27), have counts much higher than those of the remaining five phyla, totalling 25 species.

The comparatively high ascidian species count (69) can be attributed to the extensive ascidian 


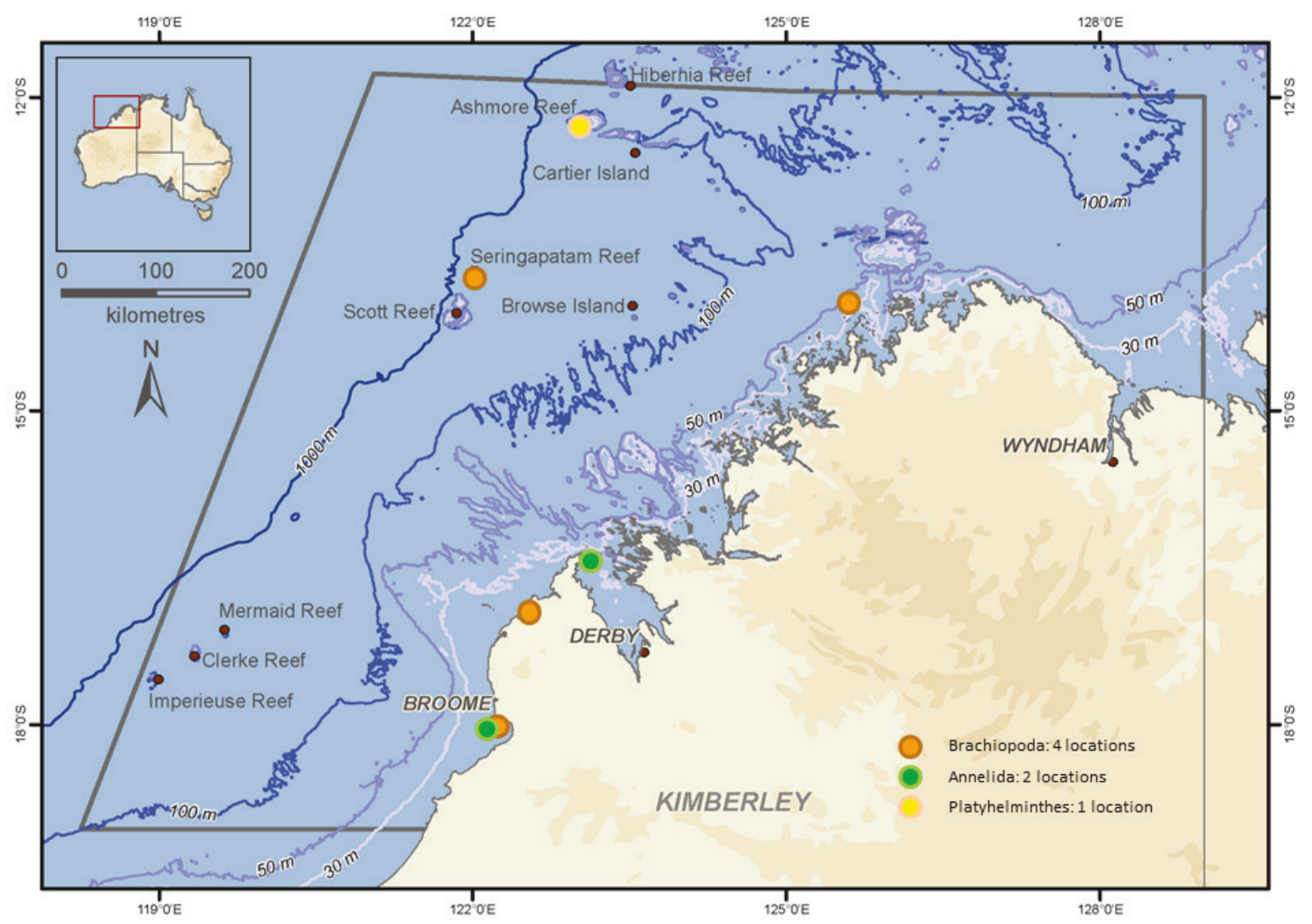

FIGURE 1 Brachiopoda locations (4 locations), Annelida (2) and Platyhelminthes (1). The Project Area boundary is marked in grey. Map projection: GDA94, Scale: 1:6, 250,000.

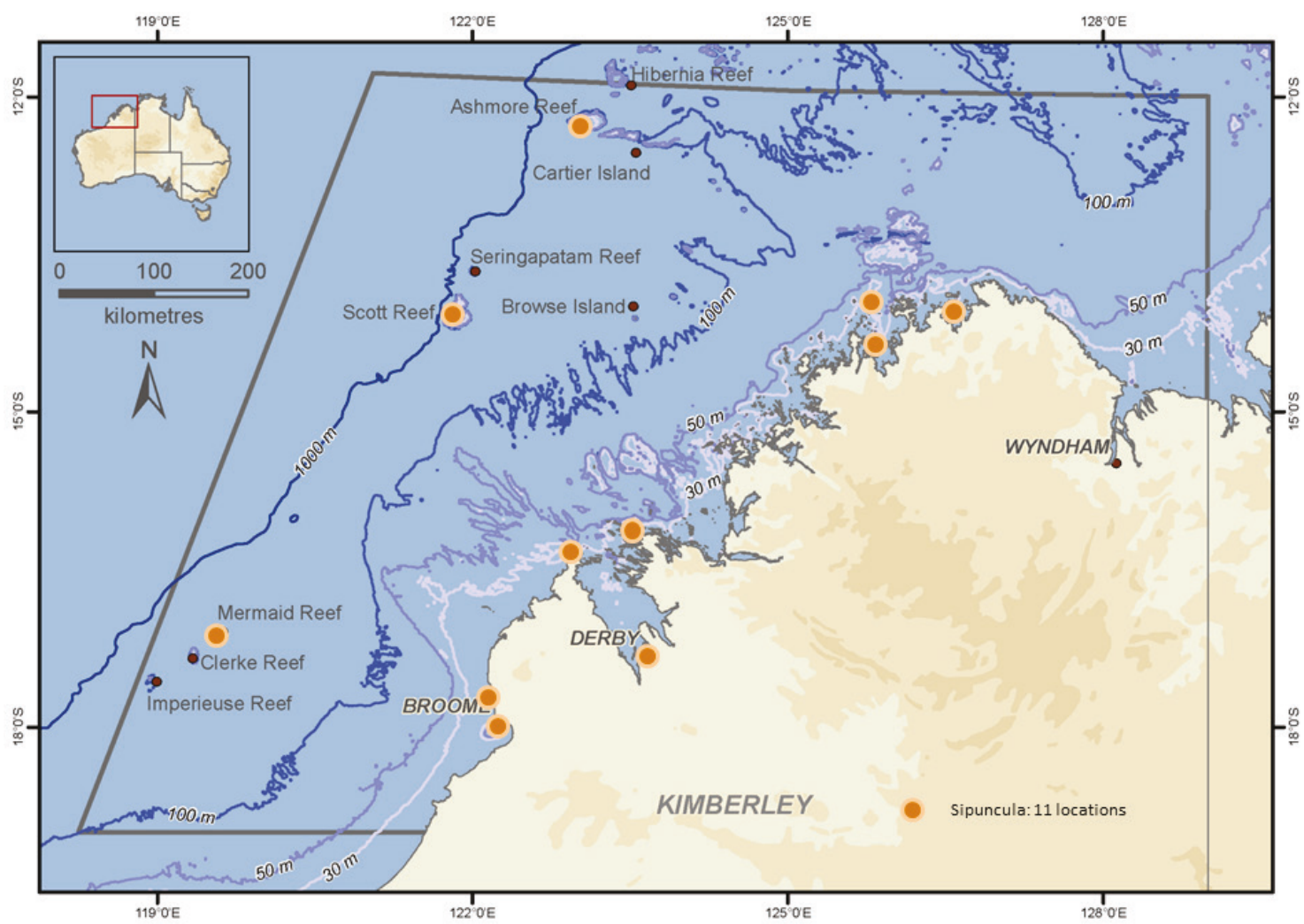

FIGURE 2 Sipuncula locations (11 locations). The Project Area boundary is marked in grey. Map projection: GDA94, Scale: 1:6, 250,000. 


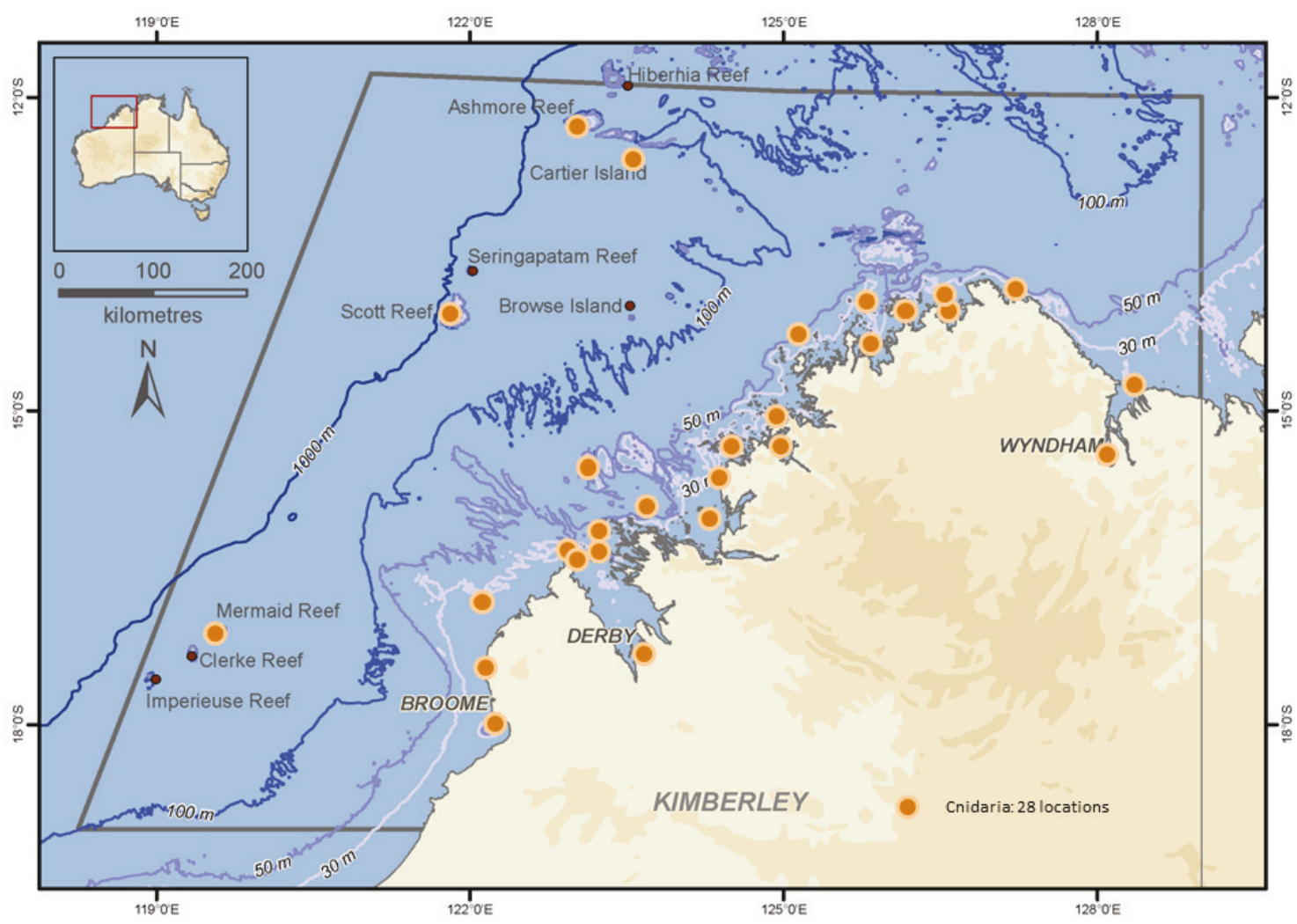

FIGURE 3 Cnidaria locations (28 locations). The Project Area boundary is marked in grey. Map projection: GDA94, Scale: 1:6, 250,000.

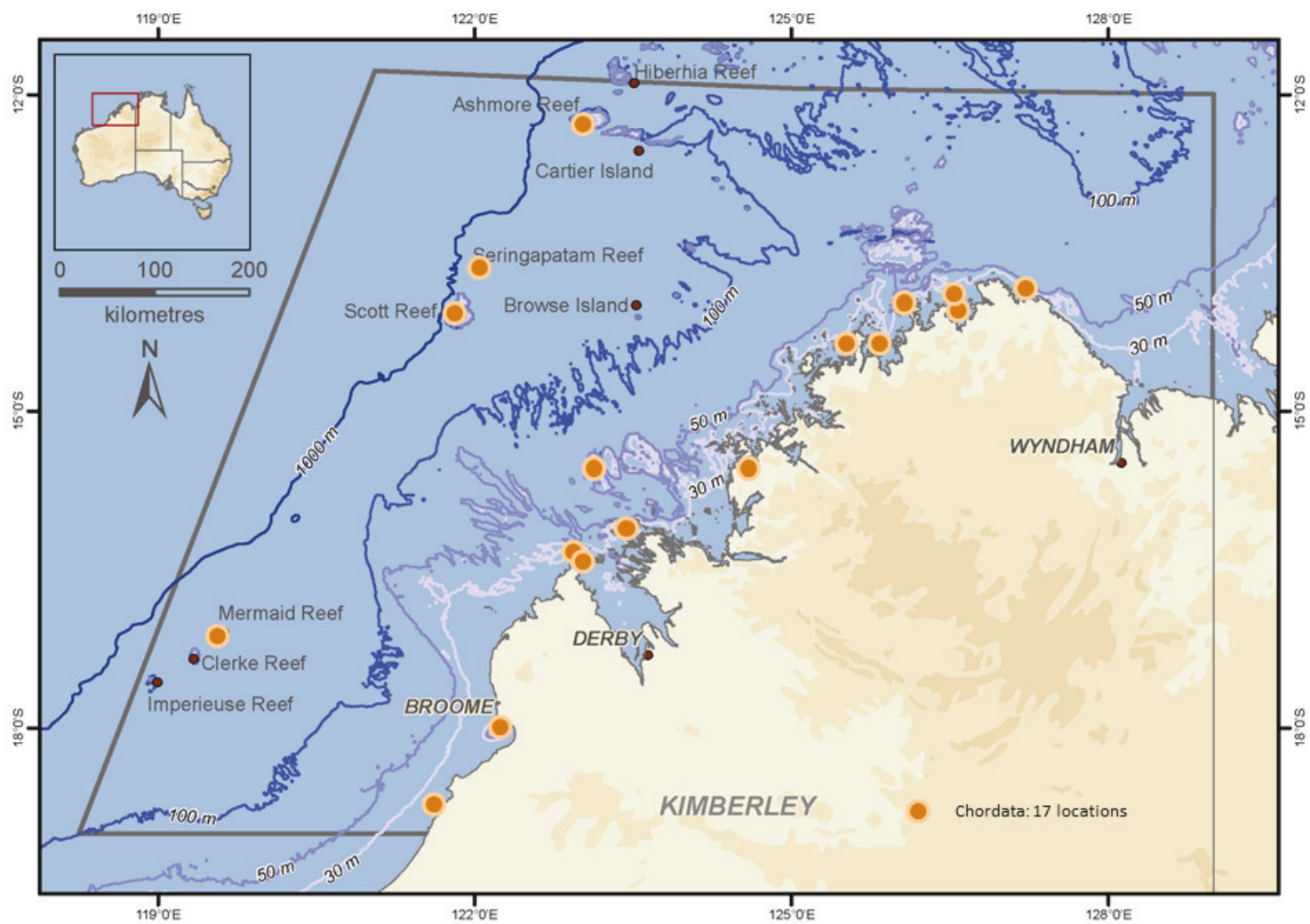

FIGURE 4 Chordata locations (17 locations). The Project Area boundary is marked in grey. Map projection: GDA94, Scale: 1:6, 250,000. 


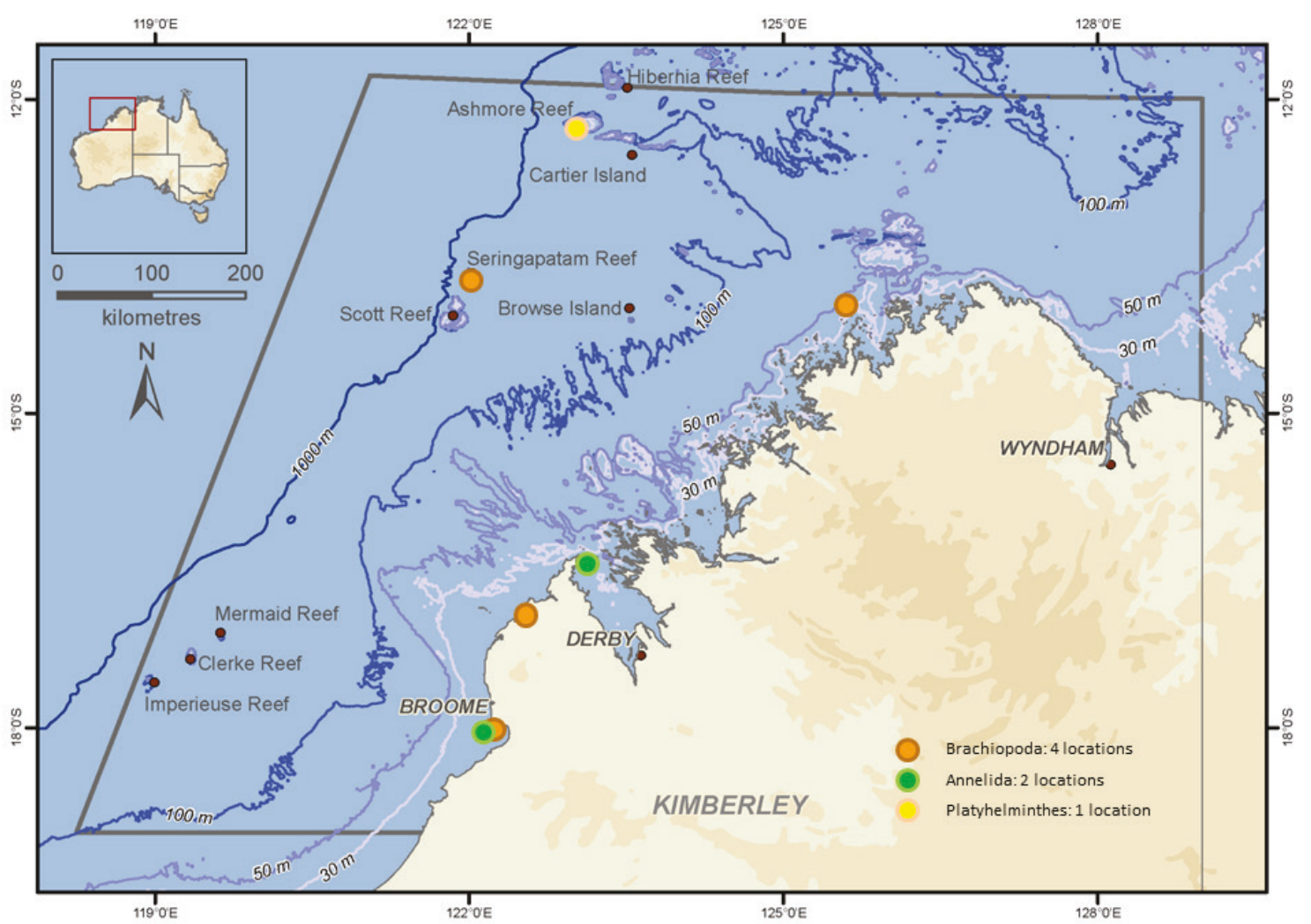

FIGURE 5 Bryozoa locations (9 locations). The Project Area boundary is marked in grey. Map projection: GDA94, Scale: 1:6, 250,000.

research of Dr. Patricia Mather (née Kott) (12 December 1925 - 4 January 2012). Kott (2006) noted that ascidians from Australian waters are known from relatively few locations and few specimens, with some known only from type specimens. Kott (2008b) reported that of the 50 known species previously recorded from Western Australia and/or adjacent locations only 21 were taken more than once. Examination of Kott's papers relevant to tropical Australia (Kott 2004, 2005, 2006, 2008a, $2008 \mathrm{~b}, 2009)$ reveal that ascidian collections, albeit far from comprehensive, were obtained from trawl and sled surveys along the north-west Australian continental edge and slope. However, very little material, other than from opportunistic collecting, was made from remote coastal Kimberley waters.

The Bryozoa, Platyhelminthes, Cnidaria and Chordata had a greater number of species from offshore compared to inshore locations, and in all cases the majority of species originated from the continental edge atoll, Ashmore Reef. Ashmore was visited by both WAM (Berry, 1993) and MAGNT (Russell et al. 2005) who conducted museum surveys, and separately by individual researchers during the 1980s and 1990s. These phyla were collected incidentally.
Twelve bryozoan species were reported in this synthesis. The British Museum collections hold over 200 bryozoan specimens from the Kimberley region, including Holothuria Bank (Cook 1965). In her paper, Cook predicted a high proportion of free-living conical bryozoan species would be represented in tropical Australian habitats similar to those found at Holothuria Bank. This habitat, consisting of sand, mud and shell, is common at many inshore Kimberley locations (Bryce personal observation) yet to be surveyed for bryozoans.

In seven previously published reports from the Kimberley (Berry 1986; Johnstone 1990; Berry 1993; Brown and Skewes 2005; Russell et al. 2005; Willan 2005; Bryce 2009), and six unpublished reports (Wells 1989; Morgan 1992; Wells et al. 1995; Walker et al. 1996; Bryce et al. 1997; Walker 1997), none reported on any of the seven phyla included in this paper, although these records represent collecting effort on these expeditions.

The current survey work (2009-2014) by WAM and partner agencies has also not incorporated these phyla into survey methodology. This can be attributed to a lack of taxonomic expertise for these phyla and collection logistical constraints. However, it also highlights that biodiversity surveys still 
focus on more abundant, and higher profile taxa, such as Scleractinian corals and fishes. Future research into these seven phyla is necessary to provide a more complete assessment of biodiversity in Kimberley marine habitats and bioregions.

\section{ACKNOWLEDGEMENTS}

The authors wish to thank the colleagues who thought to collect the specimens contained in these datasets. We extend special thanks to Stacey Osborne and Albert Miles for their indefatigable databasing and data checking skills. Woodside Energy is acknowledged for their support of this project. We thank two reviewers for helpful comments on the manuscript.

\section{REFERENCES}

Berry, P.F. (ed.) (1986). Faunal survey of the Rowley Shoals, Scott Reef and Seringapatam Reef, northwestern Australia. Records of the Western Australian Museum Supplement 25.

Berry, P.F. (ed.) (1993). Marine faunal surveys of Ashmore Reef and Cartier Island north-western Australia. Records of the Western Australian Museum Supplement 44.

Brown, K. and Skewes, T.D. (2005). A preliminary assessment of the ecology of seagrasses at Ashmore Reef. The Beagle, Records of the Museum and Art Galleries of the Northern Territory Supplement 1: 143-152.

Bryce, C.W. (ed.) (2009). Marine biodiversity survey of Mermaid Reef (Rowley Shoals), Scott and Seringapatam Reef. Records of the Western Australian Museum Supplement 77.

Bryce, C.W., Hutchins, B. and Fromont, J. (eds) (1997). Restricted marine biological survey of the "garden bottom" of Beagle Bay, Kimberley, Western Australia. Western Australian Museum: Perth. Unpublished Report.

Bryce, M., and Sampey, A. (2014). Kimberley marine biota. Historical data: soft corals and sea fans (Octocorallia). Records of the Western Australian Museum. Supplement 84: 101-110.

Cook, P.L. (1965). Notes on some Polyzoa with conical zoaria. Cahiers de Biologie Marine 6: 435-454.

Costello, M.J., Bouchet, P., Boxshall, G., Fauchald, K., Gordon, D., Hoeksema, B.W., Poore, G.C.B., van Soest, R.W.M., Stöhr, S. Walter, T.C., Vanhoorne, B., Decock, W. and Appeltans, W. (2013). Global coordination and standardisation in marine biodiversity through the World Register of Marine Species (WoRMS) and related databases. PLOS ONE 8: e51629.

Hutchings, P., Glasby, C., Capa, M. and Sampey, A. (2014). 'Kimberley marine biota. Historical data: polychaetes (Annelida)'. Records of the Western Australian Museum Supplement 84: 133-159.

Johnstone, R.E. (1990). Mangrove and mangrove birds of Western Australia. Records of the Western Australian Museum. Supplement 32.

Kott, P. (2004). New and little-known species of Didemnidae (Ascidiacea, Tunicata) from Australia (part 2). Journal of Natural History 38: 2455-2526.

Kott, P. (2005). New and little-known species of Didemnidae (Ascidiacea, Tunicata) from Australia (part 3). Journal of Natural History 39: 2409-2479.
Kott, P. (2006). Observations on non-didemnid ascidians from Australian waters (1). Journal of Natural History 40 (3-4): 169-234.

Kott, P. (2008a). Biogeographic implications of Ascidiacea (Tunicata) from the Wesssel Islands (Arafura Sea). The Beagle, Records of the Museums and Art Galleries of the Northern Territory 24: 63-67.

Kott, P. (2008b). Ascidiacea (Tunicata) from deep waters of the continental shelf of Western Australia. Journal of Natural History 42 (15): 1103-1217.

Kott, P. (2009). Taxonomic revision of Ascidiacea (Tunicata) for the upper continental slope off northwestern Australia. Journal of Natural History 43 (3132): 1947-1986.

Jones, D., Bryce, C., Fromont, J., Moore, G. (eds) (2017). Marine biodiversity of the Kimberley 1880s-2009. Records of the Western Australian Museum. Supplement 84.

Morgan, G.J. (ed.) (1992). Survey of the aquatic fauna of the Kimberley islands and reefs, Western Australia. Western Australian Museum: Perth. Unpublished Report.

Pyke, G. and Ehrlich, P. (2010). Biological collections and ecological/environmental research: a review, some observations and a look to the future. Biological Reviews 85: 247-266.

Richards, Z.T., Sampey, A. and Marsh, L. (2014). Kimberley marine biota. Historical data: scleractinian corals. Records of the Western Australian Museum. Supplement 84: 111-132.

Russell, B.C., Larson, H.K., Hutchins, J.B. and Allen, G.R. (2005). Reef fishes of the Sahul Shelf. The Beagle, Records of the Museums and Art Galleries of the Northern Territory Supplement 1: 83-105.

Sampey, A., Bryce, C., Osborne, S. and Miles, A. (2014). Kimberley marine biota. Historical data: introduction and methods. Records of the Western Australian Museum Supplement 84: 19-43.

Walker, D.I., Wells, F.E. and Hanley, J.R. (eds) (1996). Survey of the marine biota of the eastern Kimberley, Western Australia. Western Australian Museum: Perth. Unpublished Report.

Walker, D.I. (ed.) (1997). Marine biological survey of the central Kimberley coast, Western Australia. Western Australian Museum: Perth. Unpublished Report.

Wells, F.E. (ed.) (1989). Survey of the invertebrate fauna of the Kimberley islands, Western Australia. Western Australian Museum: Perth. Unpublished Report.

Wells, F.E., Hanley, J.R. and Walker, D. I. (eds) (1995). Survey of the marine biota of the southern Kimberley islands, Western Australia. Western Australian Museum: Perth. Unpublished Report.

Willan, R.C. (2005). The molluscan fauna from the emergent reefs of the northernmost Sahul Shelf, Timor Sea - Ashmore, Cartier and Hibernia Reefs; biodiversity and zoogeography. The Beagle, Records of the Museums and Art Galleries of the Northern Territory Supplement 1: 51-81.

Wilson, B.R. (2014). Kimberley marine biota: historical and environmental introduction. Records of the Western Australian Museum Supplement 84: 1-20.

World Register of Marine Species (WoRMS) (2014). http:/ / www.marinespecies.org/index.php (accessed 30 July 2016-18 January 2017). 


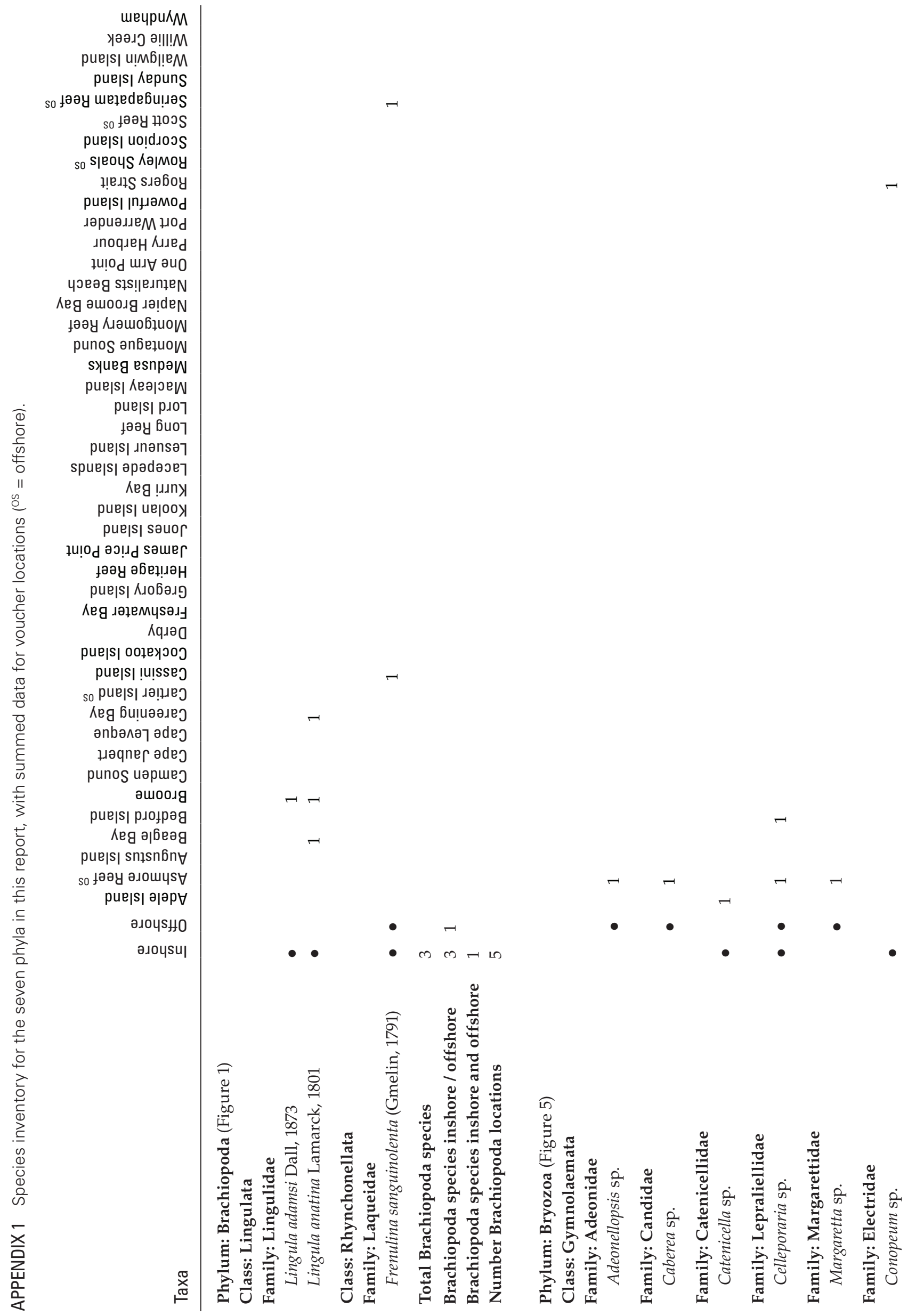




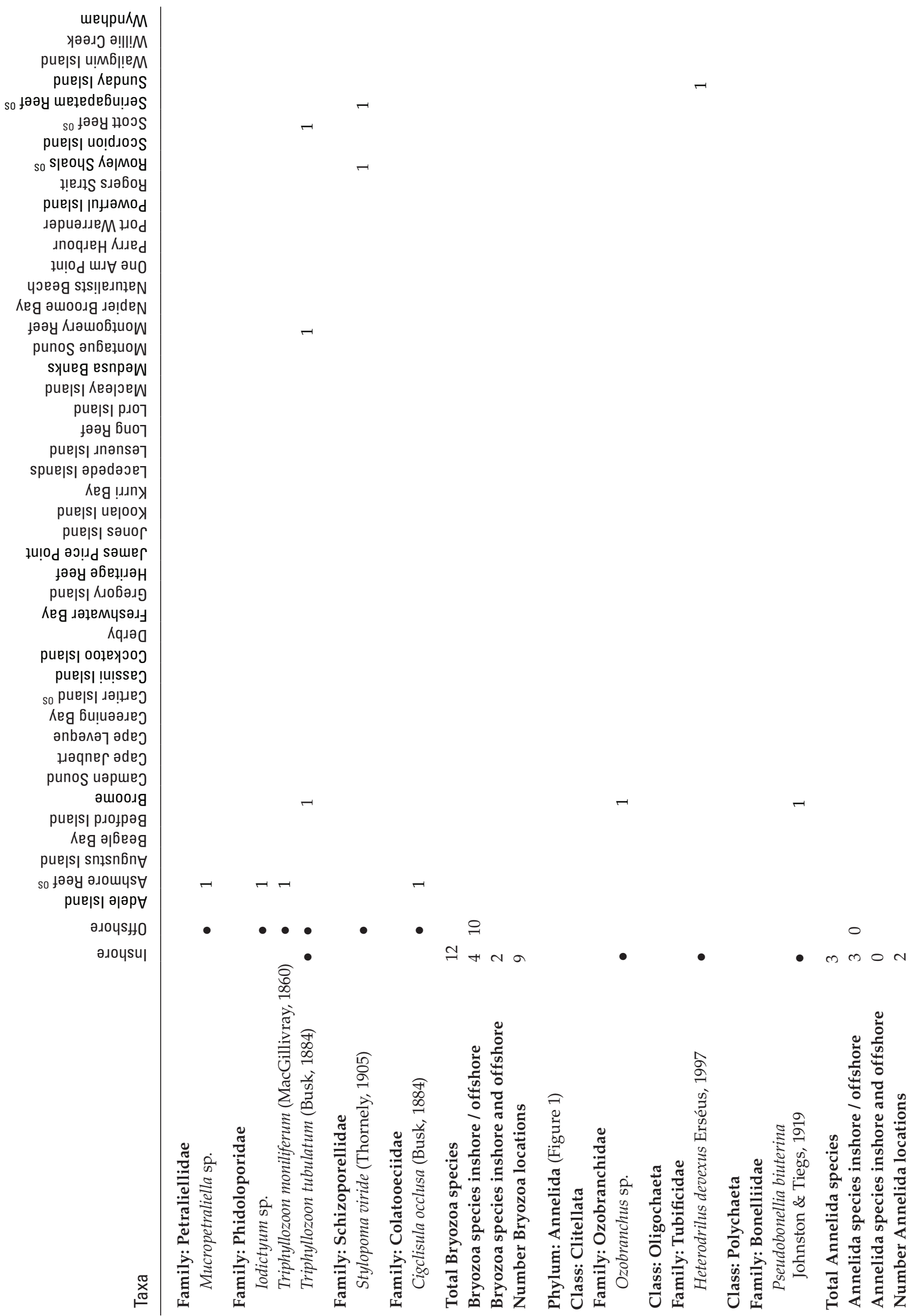




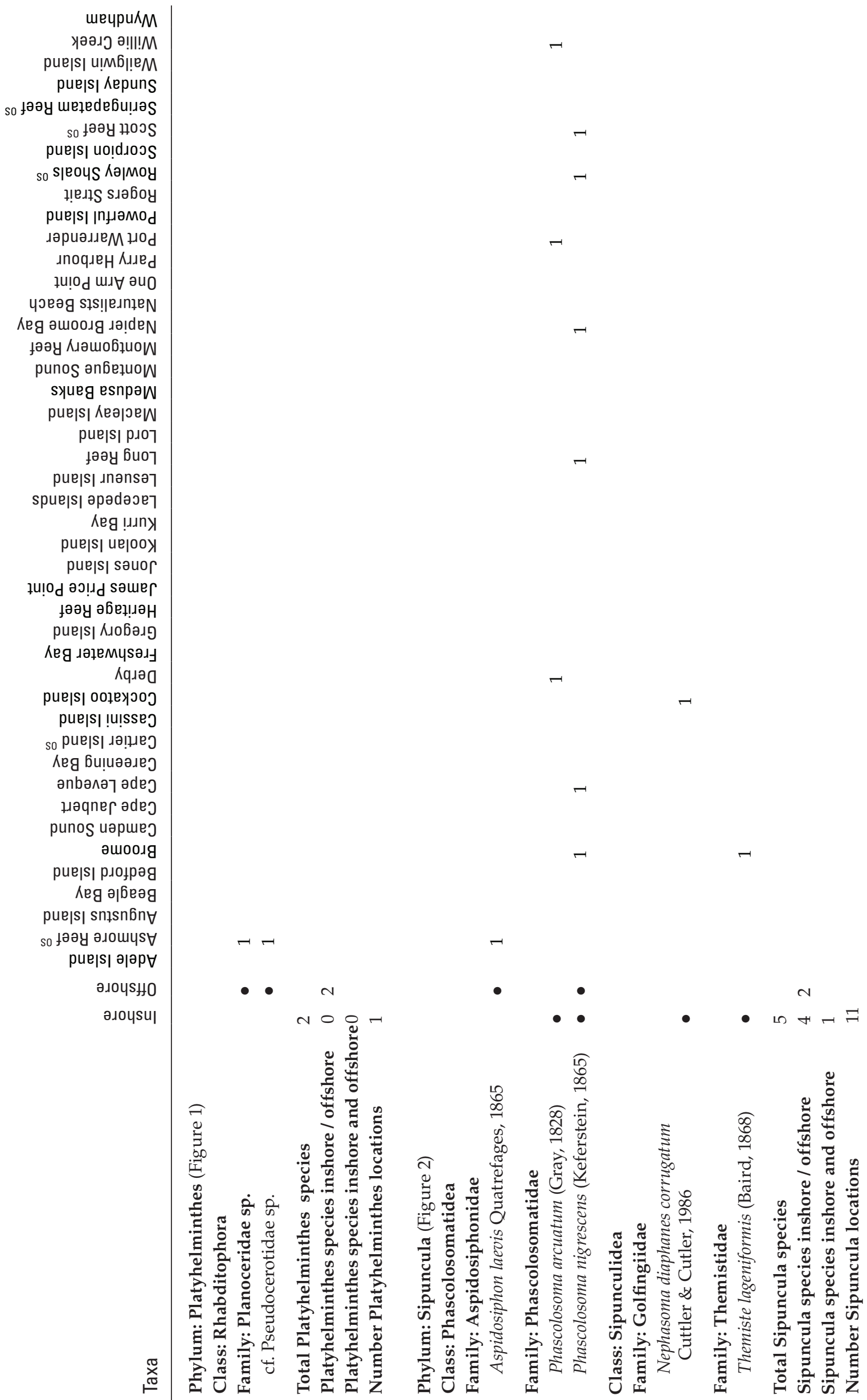




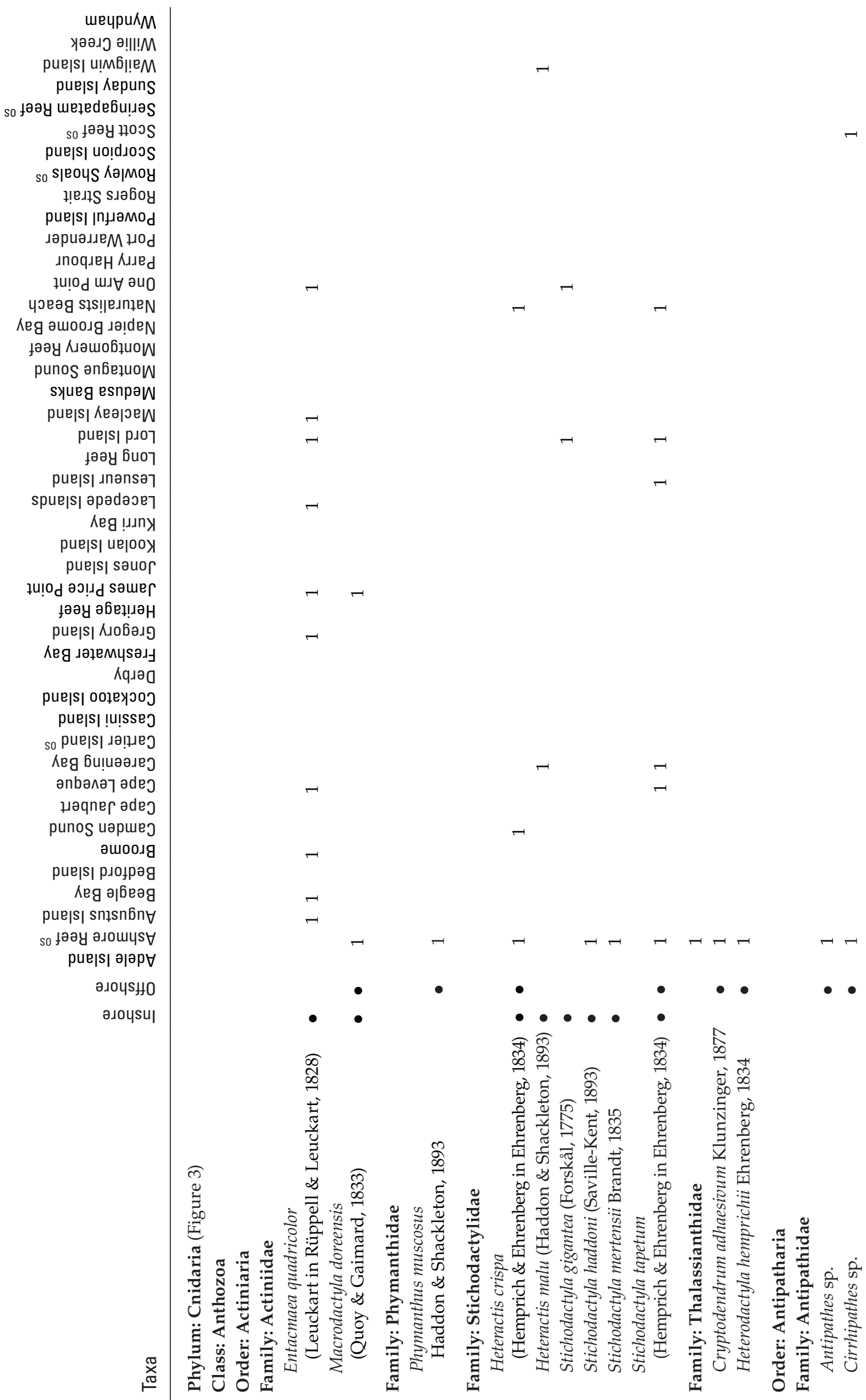




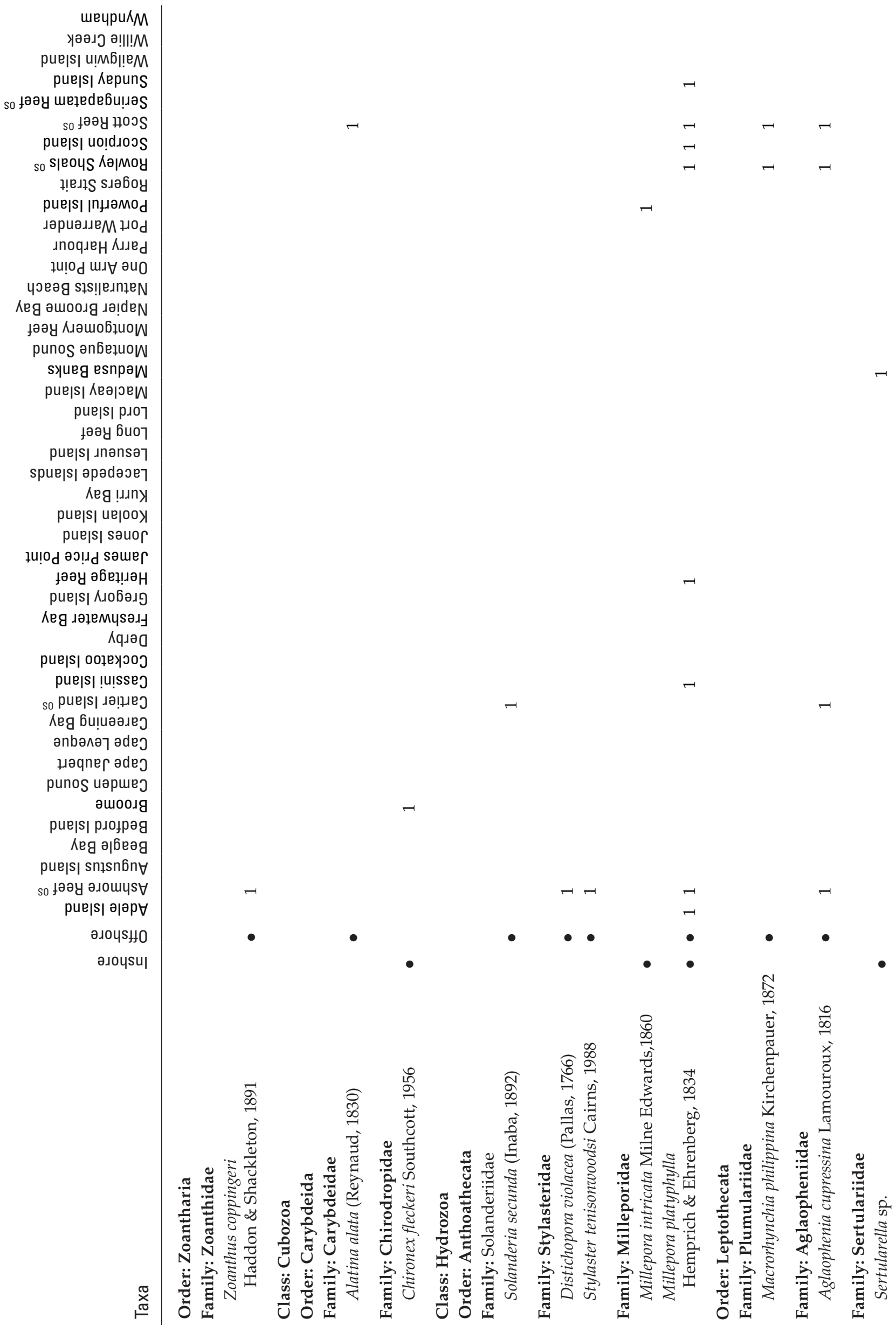




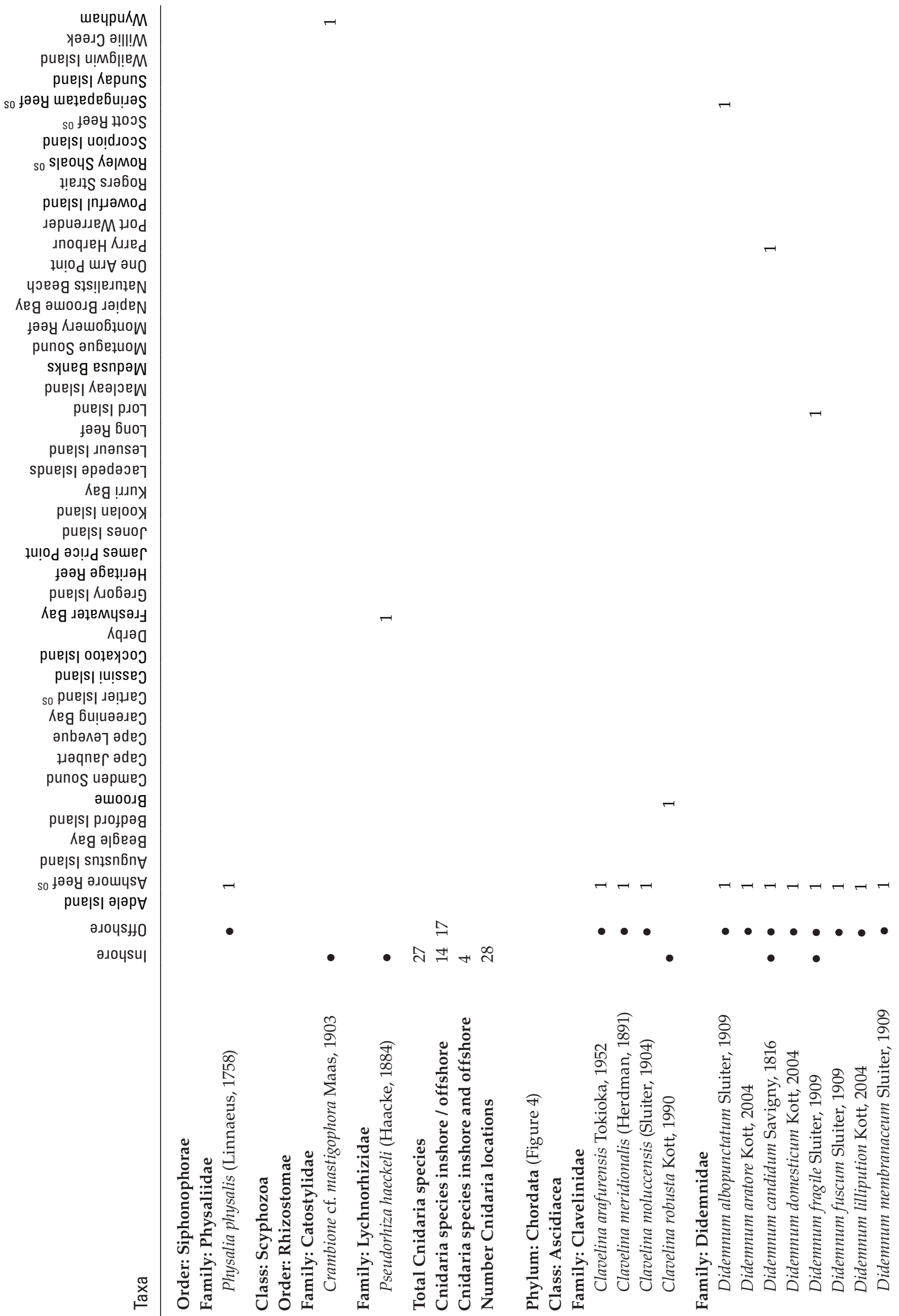




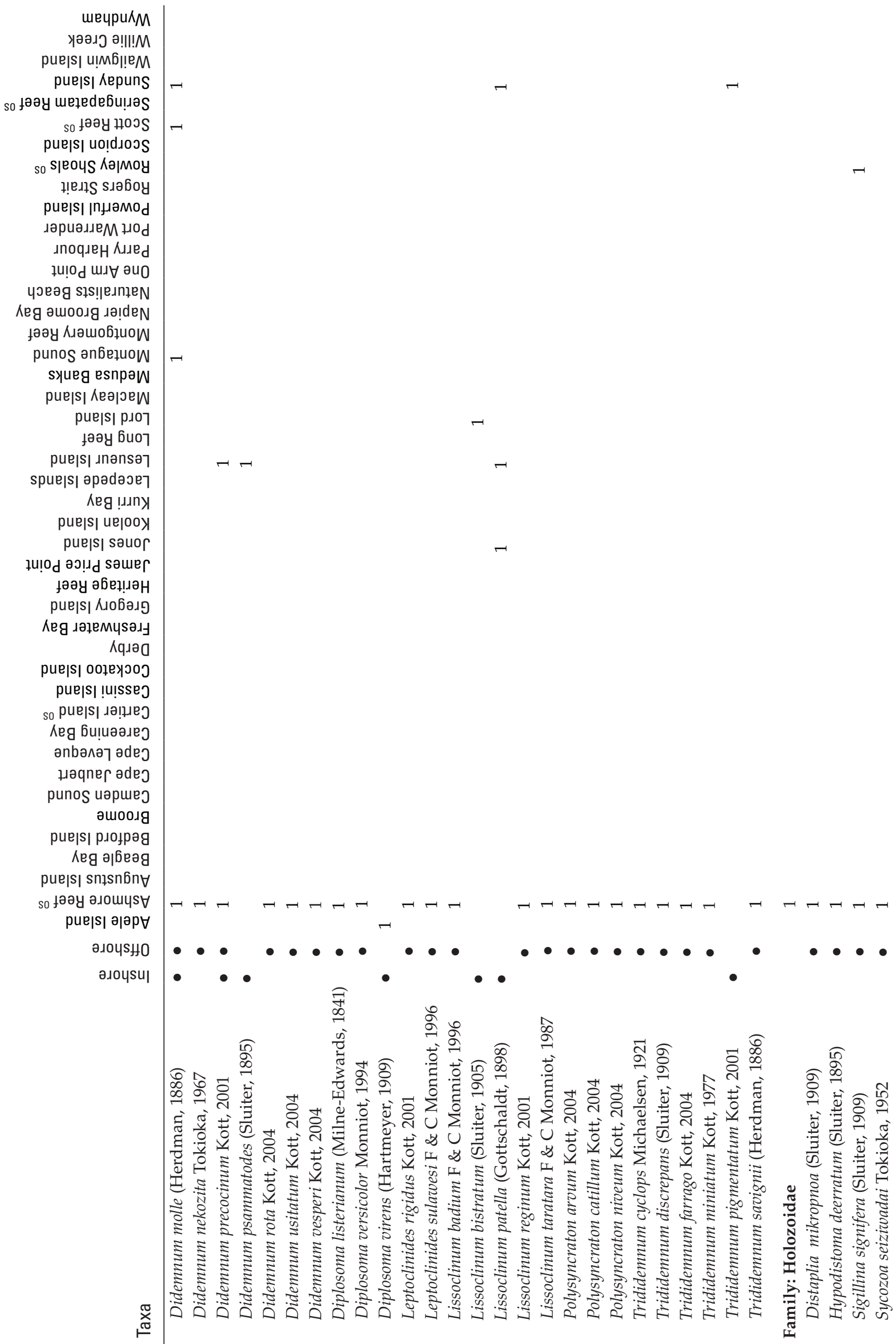




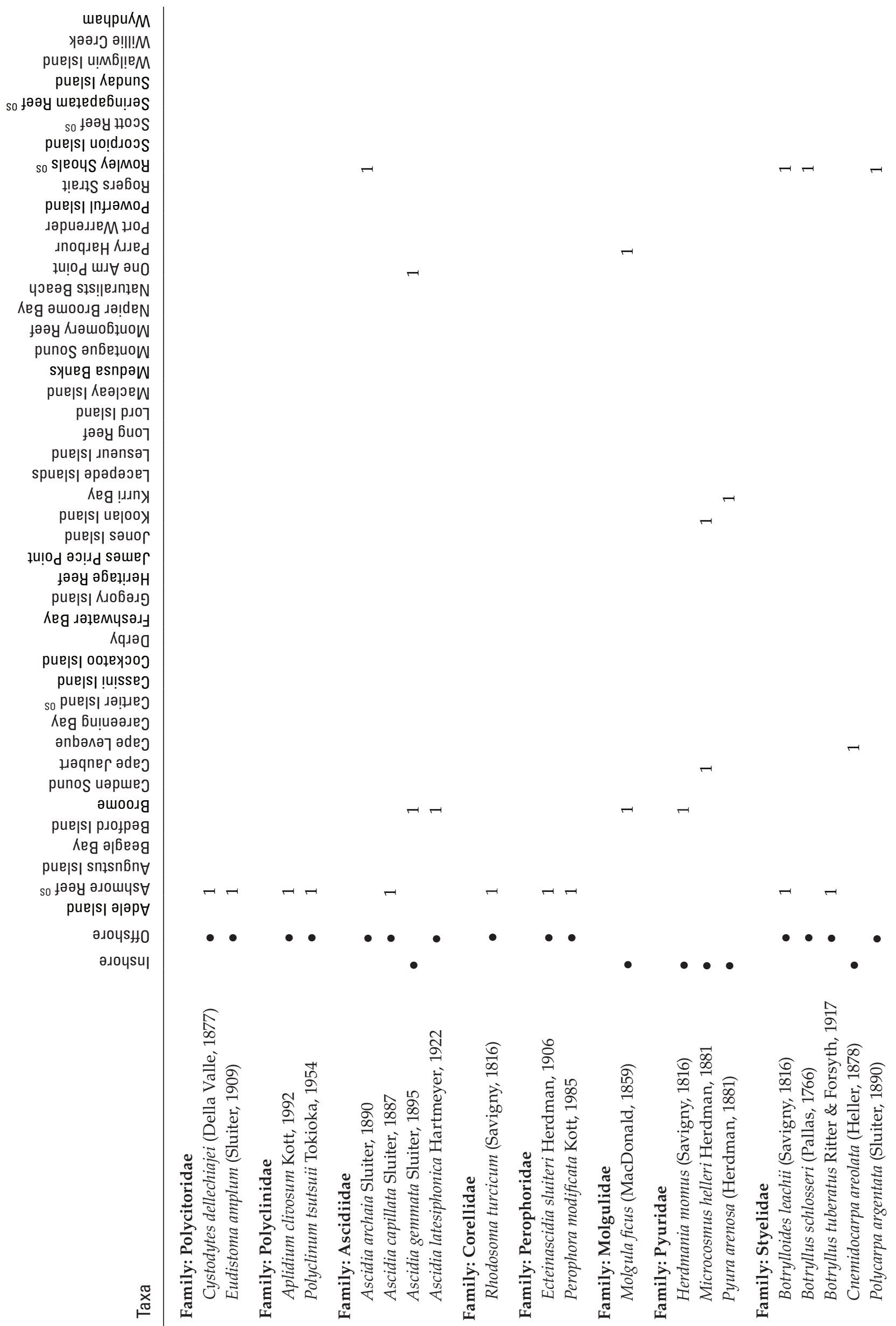




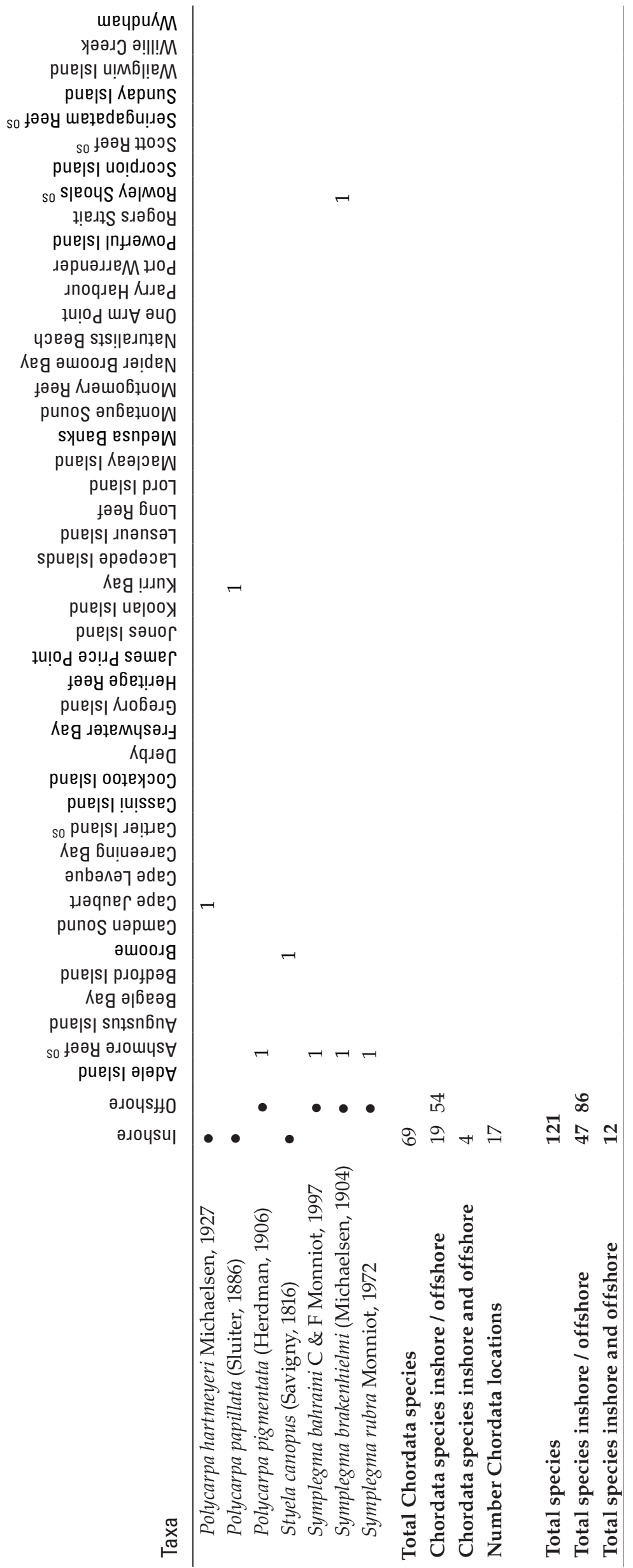


APPENDIX 2 Location and collection data for specimens included in this report (OS $=$ offshore).

\begin{tabular}{|c|c|c|c|c|c|c|c|c|c|c|c|c|}
\hline Location & $\begin{array}{l}\text { Latitude } \\
\text { (Decimal } \\
\text { Degrees) }\end{array}$ & $\begin{array}{l}\text { Longitude } \\
\text { (Decimal } \\
\text { Degrees) }\end{array}$ & $\begin{array}{l}\text { Collection } \\
\text { years }\end{array}$ & 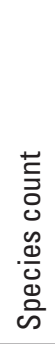 & 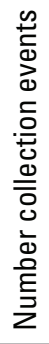 & $\begin{array}{l}\frac{\pi}{0} \\
\frac{0}{0} \\
\frac{0}{\bar{C}} \\
\frac{\pi}{\infty} \\
\end{array}$ & $\begin{array}{l}\text { D } \\
\text { N } \\
\stackrel{1}{1} \\
\text { D }\end{array}$ & 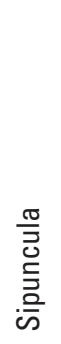 & $\frac{\frac{\pi}{0}}{\frac{0}{0}}$ & 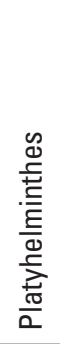 & . & $\begin{array}{l}\frac{\pi}{\pi} \\
\frac{\pi}{0} \\
\frac{0}{0} \\
\frac{c}{0}\end{array}$ \\
\hline Adele Island & -15.49707 & 123.15976 & 1990 & 3 & 1 & & $\bullet$ & & & & $\bullet$ & $\bullet$ \\
\hline Ashmore Reefos & -12.22469 & 123.01342 & $1986-2002$ & 77 & 3 & & $\bullet$ & $\bullet$ & & $\bullet$ & $\bullet$ & $\bullet$ \\
\hline Augustus I & -15.39967 & 124.57206 & 1991 & 1 & 1 & & & & & & $\bullet$ & \\
\hline Beagle Bay & -16.91552 & 122.49213 & 1988 & 1 & 1 & $\bullet$ & & & & & $\bullet$ & \\
\hline Bedford Island & -16.14178 & 123.31799 & 1989 & 1 & 1 & & $\bullet$ & & & & & \\
\hline Broome & -17.97570 & 122.23610 & 1921-2002 & 13 & 6 & $\bullet$ & $\bullet$ & $\bullet$ & $\bullet$ & & $\bullet$ & $\bullet$ \\
\hline Camden Sound & -15.54621 & 124.48663 & 1957 & 1 & 1 & & & & & & $\bullet$ & \\
\hline Cape Jaubert & -18.94047 & 121.55237 & 1983 & 2 & 1 & & & & & & & $\bullet$ \\
\hline Cape Leveque & -16.40726 & 122.91059 & 1978,1988 & 4 & 2 & & & $\bullet$ & & & $\bullet$ & $\bullet$ \\
\hline Careening Bay & -15.10048 & 125.02444 & 1998 & 2 & 1 & $\bullet$ & & & & & $\bullet$ & \\
\hline Cartier Island ${ }^{\mathrm{OS}}$ & -12.52797 & 123.55047 & 1992,1996 & 2 & 2 & & & & & & $\bullet$ & \\
\hline Cassini Island & -13.93935 & 125.62679 & 1991,1998 & 1 & 2 & $\bullet$ & & & & & $\bullet$ & \\
\hline Cockatoo Island & -16.09227 & 123.59561 & 1961 & 1 & 1 & & & $\bullet$ & & & & \\
\hline Derby & -17.32932 & 123.66716 & 1975 & 1 & 1 & & & $\bullet$ & & & & \\
\hline Freshwater Bay & -13.99410 & 126.19765 & 1913 & 1 & 1 & & & & & & $\bullet$ & \\
\hline Gregory Island & -16.31567 & 123.31276 & 1989 & 1 & 1 & & & & & & $\bullet$ & \\
\hline Heritage Reef & -14.24354 & 125.15063 & 1991 & 1 & 1 & & & & & & $\bullet$ & \\
\hline James Price Point & -17.47943 & 122.14527 & 1977 & 2 & 1 & & & & & & $\bullet$ & \\
\hline Jones Island & -13.73949 & 126.35175 & 1991 & 1 & 1 & & & & & & & $\bullet$ \\
\hline Koolan Island & -16.13496 & 123.74915 & 1978,1986 & 1 & 2 & & & & $\bullet$ & & & $\bullet$ \\
\hline Kuri Bay & -15.47389 & 124.51000 & 1964 & 2 & 1 & & & & & & & $\bullet$ \\
\hline Lacepede Islands & -16.86275 & 122.14051 & 1982 & 1 & 1 & & & & & & $\bullet$ & $\bullet$ \\
\hline Lesueur Island & -13.80000 & 127.25000 & 1991 & 4 & 1 & & & & & & $\bullet$ & $\bullet$ \\
\hline Long Reef & -13.88209 & 125.77734 & 1991 & 1 & 1 & & & $\bullet$ & & & & \\
\hline Lord Island & -16.15860 & 123.46530 & 1991 & 5 & 1 & & & & & & $\bullet$ & $\bullet$ \\
\hline Macleay Island & -15.94149 & 123.69954 & 1996 & 1 & 1 & & & & & & $\bullet$ & \\
\hline Medusa Banks & -14.65195 & 128.33742 & 1963 & 1 & 1 & & & & & & $\bullet$ & \\
\hline Montague Sound & -14.33330 & 125.55830 & 1976 & 1 & 1 & & & & & & & $\bullet$ \\
\hline Montgomery Reef & -15.93150 & 124.20481 & 1990 & 1 & 1 & & $\bullet$ & & & & & \\
\hline Napier Broome Bay & -14.05931 & 126.62001 & 1991 & 1 & 1 & & & $\bullet$ & & & & \\
\hline Naturalists Beach & -15.02600 & 125.35556 & 1988 & 2 & 1 & & & & & & $\bullet$ & \\
\hline One Arm Point & -16.43959 & 123.06824 & 1975 & 3 & 1 & & & & & & $\bullet$ & • \\
\hline
\end{tabular}




\begin{tabular}{|c|c|c|c|c|c|c|c|c|c|c|c|c|}
\hline Location & $\begin{array}{l}\text { Latitude } \\
\text { (Decimal } \\
\text { Degrees) }\end{array}$ & $\begin{array}{l}\text { Longitude } \\
\text { (Decimal } \\
\text { Degrees) }\end{array}$ & $\begin{array}{l}\text { Collection } \\
\text { years }\end{array}$ & 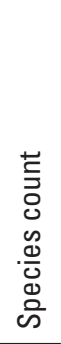 & 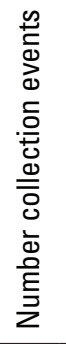 & $\begin{array}{l}\frac{\pi}{0} \\
\frac{0}{0} \\
\frac{0}{0} \\
0 \\
\frac{\pi}{\infty}\end{array}$ & $\begin{array}{l}\text { D } \\
\text { N } \\
\text { Dิ } \\
\text { ம }\end{array}$ & $\begin{array}{l}\frac{\pi}{\bar{J}} \\
0 \\
\vdots \overline{0} \\
\text { is }\end{array}$ & 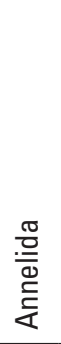 & 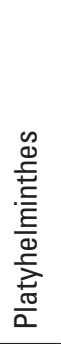 & $\begin{array}{l}. \frac{\pi}{\frac{\pi}{\pi}} \\
. \frac{\pi}{E} \\
\text { U }\end{array}$ & $\begin{array}{l}\frac{\pi}{0} \\
\frac{\pi}{0} \\
\frac{0}{0} \\
0\end{array}$ \\
\hline Parry Harbour & -13.96987 & 126.08002 & 1991 & 2 & 1 & & & & & & & $\bullet$ \\
\hline Port Warrender & -14.52651 & 125.84677 & 1976 & 1 & 1 & & & $\bullet$ & & & & \\
\hline Powerful Island & -16.08331 & 123.44091 & 1991 & 1 & 1 & & & & & & $\bullet$ & \\
\hline Rogers Strait & -15.44165 & 124.61670 & 1990 & 1 & 1 & & $\bullet$ & & & & & \\
\hline Rowley Shoals ${ }^{\mathrm{OS}}$ & -17.33581 & 119.33294 & 1982 & 11 & 1 & & $\bullet$ & $\bullet$ & & & $\bullet$ & \\
\hline Scorpion Island & -13.86664 & 126.60000 & 1982 & 1 & 1 & & & & & & $\bullet$ & \\
\hline Scott Reef ${ }^{O S}$ & -14.05426 & 121.78070 & 1984 & 8 & 1 & & $\bullet$ & - & & & $\bullet$ & $\bullet$ \\
\hline Seringapatam Reefos & -13.65903 & 122.04328 & 1984,1998 & 2 & 2 & $\bullet$ & $\bullet$ & & & & & $\bullet$ \\
\hline Sunday Island & -16.42605 & 123.18445 & 1991 & 5 & 1 & & & & $\bullet$ & & $\bullet$ & $\bullet$ \\
\hline Wailgwin Island & -15.53083 & 124.40167 & 1988 & 1 & 1 & & & & & & $\bullet$ & \\
\hline Willie Creek & -17.76360 & 122.21371 & 1975 & 1 & 1 & & & - & & & & \\
\hline Wyndham & -15.46387 & 128.12179 & 1980 & 1 & 1 & & & & & & $\bullet$ & \\
\hline Total collecting events & & & & & 56 & & & & & & & \\
\hline
\end{tabular}

